\title{
2. Att skapa motivation för främmandespråksinlärning. Effekter av tre aktiviteter $i$ en interventionsstudie $\mathbf{i}$ franska klassrum
}

Céline Rocher Hahlin

\section{Inledning}

Hur motiverar man elever att lära sig ett främmande språk? Elever som lär sig ett främmande språk gör det med olika mål och olika tankar om hur mycket tid och energi de är beredda att investera för sin språkinlärning. De har också olika benägenhet att lämna sin egen personliga bekvämlighetszon som till exempel att våga prata med fel uttal eller skapa meningar med fel grammatisk struktur vilket kan påverka deras inlärningsprocess. Ett samlat begrepp som använts i skoldebatten för att beskriva den dynamiska driftkraften vid inlärning är motivation: "Motivation, en viktig nyckel till elevers skolframgång" förklarar Lozic på Skolverkets hemsida, "Från F till E - så ökar du elevernas studiemotivation" tipsar Lärarförbundet, för att nämna två exempel. Vad menas egentligen med motivation? Enligt Dörnyei (200I) berör motivation tre aspekter av vårt agerande: anledningen till att vi väljer att göra något, ansträngningsnivån under genomförandet och processens varaktighet.

Är motivationsnivån hög bland dagens svenska elever för att lära sig ett ytterligare främmande språk än engelska? Mycket talar tyvärr för att så inte är fallet. Studier i moderna språk i grundskolan är, enligt Skolverket (20I8) "i praktiken frivilligt" eftersom eleven kan välja att läsa modersmål, svenska, svenska som andra språk, engelska eller teckenspråk i stället för moderna

Hur du refererar till det här kapitlet:

Rocher Hahlin, C. (202I). Att skapa motivation för främmandespråksinlärning. Effekter av tre aktiviteter $\mathrm{i}$ en interventionsstudie $\mathrm{i}$ franska klassrum. I Bardel, C. et al. (Red.). Forskarskolan FRAM - lärare forskar i de främmande språkens didaktik (s. 4I-64). Stockholm: Stockholm University Press. DOI: https://doi.org/Io.I6993/bbg.c. License: CC-BY 4.o. 
språk inom ramen för språkvalet. I samma rapport konstaterar Skolverket att en av fyra avgångselever från grundskolan har, inom ramen för språkvalet, läst något annat än moderna språk och att en del av elever som påbörjar studier i moderna språk avbryter studierna. Situationen förbättras inte på gymnasiet där enbart $2 \%$ av avgångseleverna väljer att läsa högre språkkurser (kurs 5, 6 eller 7) (Skolinspektion, 20I0, se vidare Cardelús, 20I6, som undersökte motivation hos elever som väljer att läsa de högre

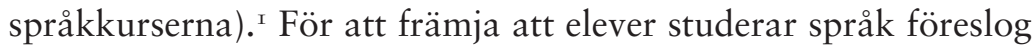
Skolverket (2018) en justering av språkvalet med en begränsning av valalternativen och en utökning av möjligheterna att läsa språk i gymnasieskolan.

Många debattörer har påpekat att språksituationen behöver förändras om inte Sveriges ställning i en flerspråkig omvärld och en alltmer internationell arbetsmarknad ska försämras ytterligare (Jansson, 20I6). Frågan, som den här studien söker svar på, är om och hur språklärare kan arbeta för en förändring. Motivationsforskning ger några intressanta ledtrådar. Hur mentala målbilder kan påverka ens val att anstränga sig vid främmandespråksinlärning har sysselsatt flera forskare under de senaste åren. Redan under I960-talet började Lambert och Gardner att undersöka vad som motiverar människor att lära sig ett främmande språk och lyfte fram betydelsen av att se upp till eller identifiera sig med en språklig målgrupp (language community) (Gardner, I99I). Några decennier senare undersökte Dörnyei, Csizér och Németh motivationen hos ungerska ungdomar som lärde sig engelska som främmande språk (Dörnyei et al., 2006). Deras slutsats blev att den motivation många av de deltagande

\footnotetext{
r På de Humanistiska, Ekonomiska, Samhällsvetenskapliga och Naturvetenskapliga gymnasieprogrammen i Sverige är modernt språk obligatoriskt i årskurs ett (steg $3 \mathrm{om}$ man fortsätter med det språket man läste på grundskolan eller steg I om man börjar lära sig ett nytt språk). Att läsa steg 4 (eller steg 2 om man har börjat med ett nytt språk) är obligatoriskt enbart på de Samhällsvetenskapliga- och Humanistiska programmen i årskurs 2 och steg 5 (eller steg 3) på det Humanistiska programmet i årskurs 3. Många program erbjuder dock möjligheten att välja en språkkurs inom individuellt val (dvs. 200 poäng som elever får disponera själv genom att välja kurser som är relevanta för dem).
} 
studenterna känner inför att lära sig ett främmande språk stimulerades genom att de kunde se sig själva som blivande framgångsrika användare av målspråket. För att analysera visionens motiverande effekt lånar Dörnyei ett begrepp som används inom psykologi, the Ideal Self.

The Ideal L2 Self beskriver den L2-ideala bilden som L2 inlärare har av sig själva. En mer detaljerad beskrivning av konceptet hittas i Ushioda och Dörnyei (2009). Henry (20I 2) kompletterade Dörnyeis resultat och idéer om den ideala språkliga självbilden då han, i sin avhandling, undersökte skolelever som studerade både engelska (som L2) och franska, spanska eller tyska som tredjespråk $\left(\mathrm{L}_{3}\right) .{ }^{2}$ På så sätt kunde Henry jämföra den ideala L2- och L3-självbilden hos svenska elever. Henrys studier kommer att presenteras mer detaljerat senare $\mathrm{i}$ texten men ett intressant resultat är att varje språk som en elev lär sig är kopplat till en självständig självbild. Dessa självbilder kan konkurrera med varandra och om man inte arbetar aktivt med strategier eller anpassade pedagogiska metoder, kan en självbild komma att kväva de andra språksjälvbilderna. Denna process är möjlig eftersom de ideala självbilderna är både rörliga och externt påverkbara (Dörnyei \& Ushioda, 2009).

Ett antal studier har testat självbildernas stimulerande effekt på inlärares lust att lära sig ett främmande språk och visat en positiv effekt av dessa aktiviteter på språkinlärningen (ökad studietid, större självförtroende, m.m.) (se till exempel Magid \& Chan, 20I 2; Dörnyei \& Chan, 2013). Dessa studier berör dock mest engelska som L2 och gjordes på universitetsnivå. Den här aktuella interventionsstudien kommer därför att studera effekten av speciell utformade Ideal Self-stimulerande aktiviteter på elevers ideala självbilder som går i årskurs nio och lär sig franska som $\mathrm{L}_{3}$.

${ }_{2}$ I denna text beskriver L2 eller $\mathrm{L}_{3}$ den kronologiska ordningen eleven har tillägnat sig språken (Hammarberg (20I0) talar om "chronological order of acquisition" (2010). L2 refererar till det första främmande språk eleverna lär sig i skolan (oftast engelska i Sverige om eleverna har svenska som första språk) och $\mathrm{L}_{3}$ refererar till det andra främmande språk eleverna lär sig i skolan (ofta franska, spanska eller tyska i Sverige). 


\section{Teoretisk bakgrund}

I slutet av I970-talet är Gardner och Lambert kritiska till frånvaron av studier som undersöker betydelsen av affektiva aspekter när man lär sig ett främmande språk, såsom intresse eller motivation (se till exempel Gardner \& Lalonde, I985). De föreslår därför en teoretisk modell som ger möjlighet att kvantitativt mäta motiverande och personliga variabler under inlärningprocessen (för en utförligare beskrivning av den socialpedagogiska modellen, se Masgoret \& Gardner, 2003). Den modellen grundas på den s.k. integrativa motivationen, dvs. viljan att likna och/eller vara en del av den gruppen som talar målspråket (som till exempel en person som har flyttat till Quebec i Kanada och önskar behärska franska för att kunna arbeta och skapa en social krets). Gardners modell bearbetas i mitten av 90-talet av Dörnyei. Han ifrågasätter betydelsen av att inläraren identifierar sig med eller vill integreras i a language community i en tid där till exempel människor reser oftare och teknologin ger nya möjligheter att kommunicera med människor från olika delar av världen.

Dörnyei utvecklar Gardners modell och skapar The $L_{2}$ Motivational Self System där fokus är ett annat: I stället för att undersöka hur inläraren avspeglar sig i en extern språklig målgrupp väljer Dörnyei att fördjupa Gardners modell med hjälp av de psykologiska begreppen the self och identity (Ushioda \& Dörnyei, 2009). Inlärares interna identifikation eller relation till det främmande språket utgör nu kärnan i inlärningsmotivationsprocessen (Ushioda \& Dörnyei, 2009). Dörnyei bygger sin modell på Markus och Nurius' (I986) studier som understryker hur mycket våra dynamiska självbilder motiverar vårt beteende. Ju tydligare självbilderna är, desto starkare kommer motivationen att bli. Dörnyei bygger även på Higgins arbete (I987) som visar att alla självbilder är unika men att de samtidigt påverkas av samhället, familjen, vänner och egna erfarenheter. Higgins kategoriserar självbilderna på följande sätt: the actual self (de egenskaper som du eller någon annan tror att du har), the ideal self (de egenskaper som du eller någon annan skulle vilja att du har) och the ought to self (de egenskaper som man eller någon annan anser att man borde ha, kopplat till ansvarskänsla, skyldighet, förpliktelse, osv.). 
I sin modell väljer Dörnyei (Dörnyei \& Ushioda, 2009) att definiera tre dimensioner av vad som motiverar språkinläraren. Han bygger på Markus och Nurius två begrepp the ideal self och the ought to self men adderar the learning experience som täcker de motiverande effekter som beror på inlärningskontexten: lärare, kursinnehåll, klasskamrater, m.m.

Dörnyeis forskning förutsätter att språkliga självbilder, om de stimuleras på rätt sätt och regelbundet (Hadfield \& Dörnyei, 20I3), kan ha en motiverande effekt på inlärarens språkinlärning och förhoppningsvis leda till bättre resultat i fortsättningen. Särskilt den ideala självbilden anses vara viktig i Dörnyeis resultat. Vi vet däremot fortfarande ganska lite om hur dessa individuella självbilder samspelar med varandra om en inlärare lär sig flera språk samtidigt, vilket är något som Henrys forskning behandlar (20I2).

I Henrys avhandling (2OI2) undersöks svenska ungdomars ideala självbilder när tidigare forskning kring motivation för främmande språk mest har fokuserat på universitetsstudenter. Dessutom fokuserar han sina studier på det andra främmande språket som elever läser i skolan (s.k. L3) vilket i Henrys studier motsvarar det svenska skolämnet moderna språk (främst franska, spanska eller tyska). De flesta tidigare studierna har huvudsakligen berört engelska, men Henry studerar interaktionen mellan elevernas ideala självbilder i L2 (engelska) och L3 (franska, spanska eller tyska). Resultaten indikerar att varje inlärt språk är kopplat till en självständig ideal självbild som utvecklas i interaktion med de andra. En elev som lär sig franska och engelska men som har en mycket mer positiv och detaljerad ideal självbild rörande engelska än vad som gäller franska riskerar att med den engelska ideala självbilden kväva den franska. De ideala självbilderna är rörliga och påverkbara av till exempel strategier som elever, som har detaljerade ideala självbilder kopplade till flera främmande språk, har hittat för att balansera självbilderna mot varandra och stimulera lusten att lära sig dessa språk bättre.

En annan viktig fråga är relationen mellan den ideala självbilden och inlärarens vilja att anstränga sig mer för att utveckla sina språkkunskaper. Rajab, Far och Etemadzadeh (20I2) undersökte med hjälp av en enkät $(n=308)$ korrelationen mellan en 
stark ideal självbild kopplad till engelska och iranska studenters vilja att anstränga sig mer (kallad intended effort) för att förbättra sina engelskkunskaper. Resultaten visar en stark korrelation mellan de båda variablerna. Ett liknande resultat redovisas av $\mathrm{Gu}$ \& Cheung (20I6) som med hjälp av en enkät ( $n=390$, alla deltagare hör till en etnisk minoritet i Hong Kong) undersökte elevernas ideala självbild (kopplad till kinesiska) och deras vilja att anstränga sig för att lära sig mer.

Även deras resultat visar att det finns en stark koppling mellan inlärares ideala självbilder (kopplade till kinesiska) och variabeln intended effort.

Sammanfattningsvis kan vi därmed konstatera att det finns indikationer om att:

- en tydlig och realistisk ideal självbild kan ha en stark effekt på inlärarens motivation att lära sig ett L2 eller ett $\mathrm{L}_{3}$

- det är möjligt för inläraren att utveckla strategier så att de olika ideala självbilderna inte stör varandra och påverkar motivationen för att lära sig flera språk negativt

- en stark ideal självbild korrelerar med inlärarens vilja att anstränga sig mer för sin språkinlärning.

\section{Tidigare studier}

Mot ovanstående bakgrund blev en naturlig fortsättning på motivationsstudierna att försöka besvara frågan om det är möjligt att utifrån, exempelvis genom lärandeaktiviteter, stimulera inlärarens ideala självbild i förhållande till ett givet språk. De empiriska studier som analyserar självbildens effekt på inlärares lust att lära sig ett främmande språk är dock relativt få och handlar oftast om universitetsstudenter med engelska som andra språk och för det mesta $\mathrm{i}$ en asiatisk inlärningsmiljö.

Magid and Chan (2012) arbetade under fyra månader med två grupper studenter (en i England, N=3 I och en i Hong Kong, $\mathrm{N}=80$ ). Målet med studien var att testa hur aktiviteter som skapades för att stimulera studenternas självbilder kopplade till engelska påverkade motivationsnivå hos studenterna. Studenterna skapade till exempel listor med egna mål i livet (både privata och professionella), beskrev på vilket sätt goda kunskaper i engelska 
skulle påverka deras studietid i England samt skrev reflekterande texter om det de skulle missa om de inte hade goda kunskaper i engelska. Deras resultat visar att aktiviteterna förstärkte studenternas ideala självbild och att motivationsnivån för att lära sig engelska samt självsäkerheten när det gäller att använda språket höjdes.

Sampson (2012) arbetade med olika aktiviteter i en grupp med kvinnliga japanska studenter som studerade engelska. Syftet med aktiviteterna var att reflektera över sina personliga mål med att lära sig engelska och se sig själva som användare av det engelska språket i en positiv och lockande bild av framtiden. Resultaten lyfter upp något intressant, nämligen att många av dessa studenter aldrig tidigare hade funderat över de egna målen med inlärningen. Sampson (2OI 2) drog slutsatsen att studenterna därför inte utvecklade en detaljerad ideal självbild kopplad till engelska. När interventionen avslutades hade dock studenterna utvecklat en personlig ideal självbild kopplad till engelska och fått en större medvetenhet om sin egen roll och möjlighet att påverka inlärningsprocessen.

Sambandet mellan motivation och interaktion med infödda talare studeras av Jauregi, de Graaff, van den Bergh och Kriz i en studie (20I2) där tjeckiska studenter som lärde sig nederländska $\left(\mathrm{N}=36\right.$, I9 på nivå $\mathrm{A}_{2}$ och $\mathrm{I}_{7}$ på nivå $\mathrm{B}_{\mathrm{I}}$ på GERS-skalan, ${ }^{3}$ Council of Europe/Skolverket, 2009) interagerade regelbundet med lärarstudenter $(\mathrm{N}=35)$ från Nederländerna under tre veckor. Studenterna fick regelbundet fylla i enkäter. Deras resultat visar att motivationen höjdes mest för de studenterna som låg på $\mathrm{A}_{2}$ nivå i nederländska (dvs. de studenter som hade den lägsta språknivån under tiden studien genomfördes). Några förändringar som nämns är att språknivån hos A2-studenterna förbättrades mest, deras upplevelse av att deras kunskaper räckte för att kunna interagera med infödda studenter stärktes under studiens genomförande och de kände sig allt mindre nervösa vid tanken att prata med infödda studenter. Studenternas skilda språknivå under studien kan vara en förklaring för hur olika effekten blev för de två

\footnotetext{
3 Gemensam europeisk referensram för språk: lärande, undervisning och bedömning.
} 
studentgrupperna. En annan möjlig förklaring är att studenterna med BI-nivå redan hade prövat på att kommunicera med infödda studenter tidigare under sina studier. Det kan ha påverkat deras upplevelse av interventionen i denna studie.

Boken Motivating Learning (Hadfield \& Dörnyei, 20I3) ska också nämnas som en av de första omfattande försök att exemplifiera möjliga pedagogiska tillämpningar av Dörnyeis modell. Boken innehåller praktiska aktiviteter som kan användas för att stärka inlärarens ideala självbilder kopplade till ett främmande språk.

Utifrån denna korta forskningsöversikt (se Rocher Hahlin, 20I4, 2020, för ytterligare diskussion) utgör följande konstateranden grunden för studien som rapporteras i detta kapitel:

- Tidigare studier visar att aktiviteter som hjälper eleverna att förstärka eller utveckla en ideal självbild kopplad till målspråket kan stödja språkläraren i att stimulera elevernas lust att lära sig mer och att underhålla den språkliga självbilden så att den positiva effekten på deras motivation inte minskar.

- Det finns sannolikt en korrelation mellan den ideala självbilden kopplad till engelska och inlärarens vilja till ansträngning men detta behöver bekräftas och kompletteras med studier som berör olika internationella skolmiljöer och olika målspråk.

- De olika faktorer som gör att den ideala självbilden varierar bland inlärare behövs dock undersökas. En intressant aspekt är till exempel om redan motiverade elever reagerar annorlunda än mindre motiverade elever på stimulerande aktiviteter och huruvida utvecklingen av den ideala självbilden förblir oförändrad över tid.

\section{Syfte och frågeställningar}

Syftet med denna studie är att undersöka vilken effekt tre olika pedagogiska aktiviteter har på elevernas motivation att vilja lära sig det franska språket $\mathrm{i}$ årskurs 9 i Sverige. Aktiviteterna utformades så att de skulle stimulera elevernas språkliga självbilder 
och hjälpa dem att tydligare se sig själva som framtida användare av det franska språket.

Forskningsfrågorna är följande:

I. Hur påverkar de pedagogiska aktiviteterna (i ämnet franska) elevernas ideala självbildsnivå kopplad till franska (ISFr)?

2. Påverkar aktiviteterna elevernas ISFr olika beroende på den ideala självbildsnivå eleverna hade före interventionen?

3. Hur starkt korrelerar elevernas ISFr och deras vilja att anstränga sig i ämnet franska?

\section{Metod och material}

En semi-longitudinell interventionsstudie genomfördes under ca. 4 månader, vilket motsvarade en hösttermin. Två variabler identifierades utifrån Dörnyeis tidigare forskning, nämligen ideal självbild kopplad till franska (ISFr) och viljan till ansträngning. Före interventionen mättes elevernas nivåer av ISFr och deras vilja till ansträngning med hjälp av en enkät ( I 6 slutna frågor, Likertskala I-4). Dessa nivåer mättes sedan efter varje aktivitet för att kunna avgöra vilken effekt respektive aktivitet hade haft. Den slutna enkäten triangulerades med fokusgruppsintervjuer och en öppen enkät vars frågor kopplades till varje aktivitet. De första nivåmätningarna användes också för att skapa fokusgrupper som skulle intervjuas under interventionen. Alla deltagande elever hade blivit indelade i tre olika grupper: låg, medel och hög nivå av ISFr. Likertskalan som användes i den slutna enkäten gav möjlighet att kvantifiera intensiteten av elevernas ISFr. Varje fokusgrupp innehöll elever från alla tre nivåer, dvs. elever vars självbilder som blivande användare av franska i framtiden var mycket, måttligt respektive föga tydliga och detaljerade.

De kvantitativa data ur den slutna enkäten analyserades statistiskt och en kvalitativ innehållsanalys gjordes för att kategorisera tematiskt svaren från den öppna enkäten respektive intervjuerna: efter att ha transkriberat de delar av intervjuerna och den öppna enkäten som var relevanta för forskningsfrågorna identifierades olika tematiska kategorier som möjliggjorde analysen av elevernas 
svar. Trianguleringen bidrog till att uppnå ett så komplett svar som möjligt på forskningsfrågorna.

Interventionen gjordes i två niondeklasser med totalt 45 elever (kallade "Mias klass", n=30 och "Emelies klass", n=I5) vid två olika grundskolor i Sverige. I studien ingick också en kontrollklass (Gudruns klass, $\mathrm{n}=\mathrm{I} 4$ ) som träffade forskaren lika ofta som interventionsklasserna men som inte arbetade med någon av aktiviteterna.

Aktiviteterna som eleverna arbetade med var (i den ordning som de presenterades för eleverna):

a. En stimulerande text (se Figur I) inspirerad av den fria skrivuppgiften Sampson använde i sin studie (20I2). Denna gång fick eleverna beskriva sig själva om några år när de, för att finslipa sina då mycket goda kunskaper i franska, har tackat ja till ett drömsommarjobb i ett fransktalande land.

Aktivitetens syfte:

- Stimulera och förstärka elevernas ISFr genom att låta dem föreställa sig vara en användare av det franska språket i en situation som de ser själva som positiv och önskvärd (se Sampson, 2012).

- Låta eleverna använda sin fantasi fritt så att självbilden blir så personlig, detaljrik, trovärdig och positiv för eleven som möjligt. På det sättet ökar chansen att självbilden stämmer överens med elevens egna drömmar och mål i livet samt harmoniserar med de andra självbilderna hos eleverna (Dörnyei \& Ushioda, 2009, Hadfield \& Dörnyei, 20I3, Dörnyei \& Kubanyiova, 20I4). För att ge eleverna möjlighet att uttrycka sig så fritt och detaljerat som de önskade skrev eleverna texten på svenska.

b. Olika inlägg på ett online-forum (www.ados.fr) för fransktalande ungdomar där eleverna skriftligt fick diskutera olika aktuella filmer och serier.

Aktivitetens syfte:

- Levandegöra gruppen fransktalande ungdomar som eleverna har läst om i läroböcker eller sett på video i klassrummet men sällan mött i verkligheten. 


\section{LE TEXTE STIMULATEUR}

Skriv en text på svenska utifrån följande scenario:

Du geår nu på gymnasiets tredje år och fortsätter att läsa franska. Du är jätteduktig, det går verkligen superbra för dig och du känner själv hur mycket lättare det är nu att prata, lyssna på talad franska i filmer eller musik. Du börjar verkligen närma dig nivån som gör att det är jättekul att kunna ett främmande språk. Därför skulle du vilja använda sommaren för att hitta ett sommarjobb utomlands och få språket att sitta perfekt.

Nu har sommaren kommit och du har fått ditt drömsommarjobb $i$ ett fransktalande land; dina planer har helt enkelt blivit verklighet.

. Var är du? Hur ser det ut omkring dig?

. Varför har du valt den här platsen?

. Har du varit där förut?

Vad jobbar du med?

. Är det som du hade tänkt dig?

. Hur är de som jobbar med dig och chefen?

. Hur bor du?

. Vem bor du med?

. Hur är de/han/hon?

. Kommer du att hålla kontakten efteråt med några av dessa människor, tror du?

. Hur reagerar människor när du pratar franska så bra?

. Hur känner du dig när du pratar flytande?

. Hur ser dina dagar ut? Hur känns det?

. Vad gör du på kvällarna?

. Hur känns det?

. Vem träffar du mest på fritiden? Hur är de/han/hon?

. Vad kommer du att komma mest ihåg från den här tiden tror du?

Figur 1. Den stimulerande texten (Aktivitet I).

- Ge eleverna möjlighet att ta kontakt och kommunicera direkt med andra ungdomar genom att använda målspråket.

- Hjälpa eleverna att inse att deras språkliga kunskaper räcker för att kunna kommunicera, på ett enkelt sätt, med andra fransktalande personer.

c. En webquest (www.zunal.com) där eleverna fick välja mellan fyra olika uppdrag som innebar att de fick möta olika delar av fransktalande kulturer (öppna en restaurang, organisera en konsert, planera en vecka i Paris och planera ett träningsläger för fransktalande ungdomar). Den positiva effekt på studenternas motivation som Altstaedter och Jones (2009) observerade efter att ha arbetat med en webquest inspirerade användningen av detta pedagogiska verktyg. 
Aktivitetens syfte:

- Ge eleverna möjlighet att lära känna inspirerande människor, deras liv och vanor eller andra kulturella aspekter kopplade till den fransktalande världen. Detta för att höja deras intresse för ämnet franska och ge dem lust att utforska den fransktalande världen på egen hand relaterat till deras egna mål och intresseområden.

- Låta eleverna skapa en levande och positiv bild av sig själva arbetande i en fransktalande miljö. Detta för att stimulera deras ISFr och därmed höja deras motivation för ämnet franska.

Klasserna arbetade helt oberoende av varandra men lärarna, Mia och Emelie, följde samma undervisningsplanering när det gällde aktiviteternas introducerande, genomförande, tidsramar mm. Kontrollklassen fick lika många besök av forskaren än interventionsklasserna. Eleverna arbetade då med pedagogiska aktiviteter som inte stimulerade medvetet elevernas ISFr.

\section{Resultat}

Studiens resultat kommer här att redovisas. För tydlighetens skull kommer presentationen att följa forskningsfrågorna. De namn på elever som används i texten är alla pseudonymer. Det bör vidare påpekas att viss exemplifiering av resultaten ges $\mathrm{i}$ avsnittet Diskussion nedan, detta för att ytterligare förtydliga resonemangen kring de resultat som framträder.

Forskningsfråga I: Hur påverkar de pedagogiska aktiviteterna (i ämnet franska) elevernas ideala självbildsnivå kopplad till franska?

De viktigaste resultaten kan sammanfattas i följande punkter (se Rocher Hahlin, 2020 för en utförligare redovisning):

- De kvantitativa resultaten är blandade. I Mias klass visar resultaten en signifikant förändring av ISFr i positiv riktning under interventionen $(\mathrm{p} \leq 0.05)$ medan i Emelies klass visar resultaten ingen signifikant effekt av aktiviteterna på elevernas ISFr. 
- De kvalitativa resultaten som baseras på de öppna enkäterna och gruppintervjuerna visar att aktiviteterna har upplevt av många elever som motivationshöjande. När elevernas svar hade kodats och analyserats utifrån den effekten aktiviteterna hade haft pekade $90 \%$ av eleverna i Mias klass på en positiv effekt. I Emelies klass uttrycker $40 \%$ av eleverna att aktiviteterna haft en positiv effekt och $30 \%$ av eleverna att aktiviteterna varken har haft en positiv eller negativ effekt. Dessa resultat indikerar att en process har satts igång genom arbetet med aktiviteterna. Många elever lyfter under fokusgruppsintervjuerna fram hur nytt det var för dem att fundera över en potentiell användning av det franska språket i deras framtida liv. Under det avslutande gruppsamtalet menade många elever att de upplevde franskan som närmare deras vardag och deras egna intressen, mycket tack vare arbetet med autentiska aktiviteter. Ytterligare belysning av de kvalitativa resultaten följer i diskussionen nedan.

Forskningsfråga 2: Påverkas elevernas ISFr olika beroende på den ideala självbildsnivå eleverna hade före interventionen?

- När elevernas kvalitativa svar ur den öppna enkäten och fokusgruppsintervjuer kodades och analyserades utifrån effekten aktiviteterna hade haft, ${ }^{4}$ anger $75,5 \%$ av eleverna i grupp hög en mycket positiv effekt (gäller båda klasserna sammantaget). I gruppen medel var $52 \%$ av eleverna mycket positiva till aktiviteterna. Motsvarande siffra för gruppen låg var $40 \%$.

- På klassnivå visar eleverna i Mias och Emelies klasser på olika utveckling: I Mias klass förstärks elevernas självbilder i alla tre grupper med olika ISFr (hög, medel och låg), medan de försvagas något $\mathrm{i}$ gruppen med den lägsta nivån av ISFr före interventionen i Emelies klass (grupp låg). Under intervjuerna berättar vissa elever från denna grupp att de

${ }^{4}$ Elevernas svar sorterades efter tre kategorier: en positiv effekt, ingen effekt och en negativ effekt. 
inte vill binda sig, vare sig kognitivt eller emotionellt, till ämnet franska. Eleverna anser att den typ av aktiviteter som provades under interventionen kommit för sent i utbildningen. De uttrycker att de troligen skulle känna annorlunda för ämnet om de hade arbetat med denna typ av självbildshöjande aktiviteter i tidigare skolår.

Forskningsfråga 3: Hur starkt korrelerar elevernas ideala franska självbildsnivå och deras vilja att anstränga sig i ämnet franska?

- Studien förstärker tidigare resultat gällande engelska som L2: den starka korrelationen mellan variablerna IS (Ideal Self) och vilia till ansträngning bekräftas i franska som $\mathrm{L}_{3}$. Pearsons korrelationstest visar på ett starkt samband mellan de två variablerna $(\mathrm{r}=.80)$. De elever som har en stark självbild i franska ger också uttryck för en stark vilja till ansträngning i ämnet och omvänt.

\section{Diskussion}

De pedagogiska aktiviteternas påverkan på elevernas ISFr

De aktiviteter som användes i den här interventionsstudien skapades utifrån faktorer som i tidigare studier visat sig kunna stimulera inlärarens ideala självbild kopplad till ett visst språk. Ett av huvudmålen med studien var att undersöka om dessa aktiviteter, som teoretiskt skulle kunna höja elevernas motivation, hade en positiv effekt på elevernas ISFr och därmed deras motivation att lära sig franska.

Den slutna enkätens svar visar en liten signifikant effekt i Mias klass och ingen signifikant effekt i Emelies klass på elevernas ISFr. Interventionen pågick under fyra månader och eleverna arbetade med tre pedagogiska aktiviteter. Tiden som behövs för att ändra ett beteende eller en vana varierar mycket i förhållande till individ, mål, anledningar till förändringen, etc. Förändringen tar tid, särskilt eftersom det inte handlar om en plötslig händelse i det här fallet utan om en process med olika steg. En tolkning av resultaten är att interventionen blev ett första steg för att förändra elevernas medvetenhet om betydelsen av ämnet franska för dem själva. 
Samtidigt varade interventionen sannolikt en för kort period och innehöll inte tillräckligt många uppgifter för att resultera i en tydligare förändring av ISFr.

För de elever som inte ens har påbörjat (eller inte vill påbörja) processen att stimulera sin ISFr med hjälp av drömmar, framtidsplaner, etc. behövs troligen längre tid innan ett tydligt resultat kan bli synligt med de kvantitativa metoderna. Lotta (Emelies klass, grupp medel ISFr) utgör ett exempel på en elev som inte ser sig själv använda franska i framtiden.

Lotta: Jag tror inte att det kommer att hända... att jag àker till ett fransktalande land och snackar franska. Jag har inte det intresset som krävs för att komma på den nivån. I sådana fall skulle det vara typ med engelskan, inte med franskan.

Intressant att beakta när man jämför resultaten från denna studie med Magid och Chans (20I2) signifikant positiva utveckling av studenternas ideala självbilder (kopplade till engelska) är att studenterna i deras studie fick en introduktion till vad konceptet ideal self innebär. Magid och Chan berättade inledningsvis att studenters visualisering av framgångsrika självbilder kunde höja motivationen för att lära sig engelska. Studenterna i deras studie var alltså förberedda på aktiviteterna och deras möjliga effekt på ett annat sätt än vad eleverna i denna studie var. Det skulle vara intressant att undersöka på vilket sätt den här explicita presentationen påverkar inlärarens deltagande och studiens resultat.

Trianguleringen av undersökningsverktygen i denna studie gav möjlighet att komplettera enkätens kvantitativa resultat med kvalitativa data som samlades in med hjälp av öppna enkäter samt intervjuer. I en studie som denna är kvalitativa data viktiga. De ger forskaren möjligheten att få en bättre förståelse för processen. Eleverna fick själva sätta ord på hur aktiviteterna hade påverkat deras ISFr och deras svar kodades. $90 \%$ av eleverna i Mias klass kodades som positiva svar och $70 \%$ av eleverna i Emelies klass som positiva eller neutrala. Ett annat viktigt resultat i studien är att inget elevsvar om aktiviteternas effekt på deras ISFr kategoriserades som "negativ effekt".

Ett talande exempel är Sibel (i Mias klass) som hör till gruppen som hade den lägsta nivån av ISFr före interventionen (grupp låg) 
och som vid sista intervjun berättar om effekten som aktiviteterna har haft på hennes ISFr.

Sibel: Förut, ... i alla fall jag visste inte riktigt varför jag gick på franskan nästan... det kändes som liksom ingen idé... att kunna det men om man gör såhär [arbetar med aktiviteter som stimulerar elevers ISFr] så märks det att det kan vara bra att kunna det. [...] Det [franska] känns mer levande, det känns mer på riktigt.

Sibels reaktion bekräftar Sampsons (20I2) observation att många studenter inte har en utvecklad självbild kopplad till målspråket före en intervention av den typ som genomförts här. ${ }^{5}$

I ett samhälle där visualisering av självbilder använts inom till exempel idrott, medicin eller psykologi är det förvånande att skolans stöddokument (som kommentarmaterial eller fortbildningsmaterial till exempel) inte nämnt tidigare vilken betydelse sådana stimulerande aktiviteter skulle kunna ha för språkelevernas motivationsutveckling. ${ }^{6}$

De positiva aspekterna av aktiviteterna är enligt eleverna följande:

Aktiviteterna har hjälpt dem att...

- förstå att franska är bra att kunna utanför klassrummet

- skapa en tydligare bild av deras egna mål med språket (yrkesliv, resor, media, möte, osv.)

- stimulera deras lust att använda språket aktivt

Jakob (Mias klass, grupp hög ISFr) sammanfattar väl de tre effekter som aktiviteterna, enligt eleverna, kan ha/har haft på dem.

Jakob: Att få träffa folk runt i världen och lära sig hur de lever är något jag skulle uppskatta. [...] Det känns som ett mål att kunna prata franska.

5 "[The study] revealed that the majority of students, whilst holding an intention for their future, did not have a detailed image of their future Englishusing self" (Sampson, 2012, s. 332 ).

${ }^{6}$ Först 20I 8 tar skolverkets kompetensutvecklingsinsats Språksprånget upp hur lärarna kan arbeta med språkliga självbilder (i modulen Muntlig språkutveckling). 
Om man tittar på de negativa aspekter som nämndes av eleverna hade de inte direkt med aktiviteterna att göra utan med ämnet franska i stort. Några elever berättar att de redan har lämnat ämnet franska bakom sig. De vill inte ens försöka att intressera sig för det. Dessa elever pratar positivt om aktiviteterna men uttrycker att deras allmänna ideala självbild (dvs. hur de vill vara som människa) skiljer sig för mycket från en ideal självbild där franska skulle ingå. Andreas (Emelies klass, grupp låg ISFr) uttrycker tydligt i den andra delen av citatet att han inte ser någon nytta $i$ att anstränga sig för att lära sig franska.

Andreas: Jag gillar inte franska. Det är onödigt med franska.

Andreas svar kan kopplas till ett viktigt men fortfarande för lite utforskat ämne inom språkinlärning; demotivation och amotivation $^{7}$ (Dörnyei och Ushioda, 20II: I38-I42). Vi behöver flera studier som undersöker dessa tillstånd för att kunna hjälpa elever som, liksom Andreas, inte verkar se meningen med ämnet franska.

Den allmänna bilden som de kvalitativa data ger stämmer $\mathrm{i}$ stort överens med tidigare studier (Dörnyei \& Ushioda, 2009, Henry, 20I 2, Magid \& Chan, 20 г 2, Sampson, 20 2, m.fl.). Flera elever, som till exempel Johanna (Emelies klass, grupp hög ISFr), bekräftar att det är mycket motiverande att betrakta språkliga kunskaper som berikande och betydelsefulla för de egna livsplanerna, att kunna föreställa sig själv i en trovärdig situation där språket används aktivt och att ju tydligare och trovärdigare bilden är, desto större är lusten att lära sig.

Johanna: Jag ska kunna spräket [franska] en dag... [...] Man kan nog vilja lägga mer tid på franska för man fär en mer personlig bild av Frankrike och förstår att det inte bara är ett oanvändbart ämne att plugga av $i$ skolan. Det är till för att nå ett ändamål.

7 Demotivation concerns specific external forces that reduce or diminish the motivational basis of a behavioural intention or an ongoing action” (Dörnyei \& Ushioda, 20II:I39).

"Amotivation refers (according to Deci and Ryan, I985) to the relative absence of motivation that is caused by the individual's experiencing feelings of incompetence and helplessness when faced with the activity" (Dörnyei \& Ushioda, 201 I: I 40). 
Andra elever, som Ian (Mias klass, gruppen medel ISFr), vittnar också tydligt om att aktiviteterna har satt igång en process.

Ian: Jag tror att dessa uppgifter har gjort franskan nyttigare för mig.

Aktiviteterna har aktiverat en motiverande process bland eleverna. Vi kommer nu att undersöka om aktiviteternas effekt berör alla elever på samma sätt eller om den varierar beroende på elevernas nivå av ISFr före interventionen.

Aktiviteternas påverkan på elevernas nivå av ISFr i förhållande till deras nivå av ISFr före interventionen

Elevernas nivå av ISFr före interventionen visade sig spela en viktig roll för studiens resultat. Jauregis, de Graaffs, van den Bergs och KrizIs studie (2012) visade att det var studenter med den lägsta språkliga nivån som blev mest motiverade av det utbyte som skapades mellan infödda och studenterna. Till skillnad från Jauregis och hennes kollegor (20I2) visar den här föreliggande studien att ISFr hos alla grupper utvecklas enligt samma mönster (se nedan), utom i gruppen hög hos Maria där ISFr höjs regelbundet under hela interventionen och i gruppen låg hos Emelie där den minskar under interventionen.

Ett liknande mönster hittades i de flesta elevgrupper:

- en positiv effekt efter den stimulerande texten (aktivitet A ovan) vars huvudsyfte var att kunna skriftligt (i ett valfritt språk som forskaren kunde förstå) detaljera sin vision och koppla den direkt till en framtida positiv situation.

- en liten negativ effekt efter arbetet med forumet online där eleverna själva fick förstå och besvara några inlägg (aktivitet B ovan). Detta krävde att eleverna använde sina språkkunskaper och dessutom lite mod att lämna sin komfortzon eftersom det innebar att exponera sin språkanvändning för utomstående och dessutom infödda språkanvändare. Den uppgiften var säkert den mest utmanande i den meningen.

- en positiv effekt av arbetet med en av fyra webquests (aktivitet $\mathrm{C}$ ovan) där eleverna arbetade i små grupper och valde 
den uppgiften de gillade mest. Här kunde de använda sin kreativitet, sina intressen för att nå målen.

Ett intressant resultat är effekten på gruppen med den högsta nivån av ISFr före interventionen i Mias klass och gruppen med den lägsta nivån av ISFr före interventionen i Emelies klass. En möjlig tolkning av dessa resultat är att det finns en nedre gräns för ISFr som elever inte kan ligga under om deras ISFr ska kunna påverkas externt. En sådan tolkning skulle kunna betyda att vissa elever har en nivå av ISFr som ligger för långt från en konkret användning av franska i förhållande till sitt framtida själv (future self) för att internt kunna starta en motiverande process. Detta måste dock undersökas närmare i framtida forskning.

Framtida studier skulle också kunna följa en klass där ISFrstimulerande aktiviteter införts när eleverna börjar lära sig målspråket för att se om elever som Andreas (se ovan) eller Hedda (se nedan), dvs. elever som inte alls ser meningen med att anstränga sig för att lära sig franska, återfinns i samma antal som i denna studie. Hypotesen skulle vara att de är färre eftersom elevernas ISFr skulle utvecklas regelbundet och från början med hjälp av aktiviteterna.

Därmed kan man förvänta sig att medvetenheten om betydelsen av att lära sig det främmande språket för sin egen del skulle växa och stärka motivation hos eleverna - särskilt kanske hos elever som önskar kunna språket men inte tar initiativ till inlärningsprocessen som till exempel Hedda som deltog i studien:

Hedda (Emelie, grupp medel ISFr): Det är typ "Oj, vad kul om det kunde hända" [=det som hon skrev om $i$ det stimulerande texten] men det är ingenting man riktigt skulle kämpa för.

Samband mellan elevernas ISFr och deras vilja att anstränga sig i ämnet franska

Vad gäller korrelationen mellan dessa båda variabler är studiens resultat mycket tydliga: det finns ett mycket starkt samband mellan nivån av ISFr och elevens vilja att anstränga sig för sin språkinlärning. Detta bekräftar andra studiers resultat som Rajabs och hennes kollegor (20I2) eller Sung and Tsais (20I3). Dessa 
studier undersökte studenter som lärde sig engelska i den första studien och arabiska, kinesiska, franska, tyska, japanska, portugisiska och spanska i den andra. Denna studie kompletterar deras resultat med informationen om att korrelationen är lika stark när det gäller I 5-åriga svenska ungdomar som lär sig franska.

Det är ur en pedagogisk synvinkel ett uppmuntrande resultat. Studien indikerar att elevernas ISFr korrelerar med elevernas vilja att anstränga sig och att aktiviteterna i studien satt igång en extern stimulans av elevernas ISFr. Skulle lärarna som börjar tidigt och regelbundet att använda aktiviteter som stimulerar elevernas ISFr förbättra elevernas självbilder kopplade till franska och höja deras vilja att anstränga sig avsevärt, skulle detta arbetssätt hjälpa lärarna som idag upplever svårigheter att motivera vissa elever. De elever som beskrev sig själva som helt ointresserade av ämnet franska under intervjuerna hade läst tre till fyra år franska. Att introducera liknande aktiviteter då är kanske redan för sent för de elever som har byggt upp en stark negativ bild om sig själva i förhållande till ämnet och språket franska.

\section{Slutsats}

Den här studien föddes ur en frustration av att möta språkelever som saknade motivation för ämnet franska och ur viljan att hitta intressanta pedagogiska spår för att öka lusten att lära sig det franska språket. Grunden till studien är Dörnyeis teori om betydelsen av självbilder för främmandespråkinlärning. Dörnyei menar att en inlärare som kan föreställa sig själv i en konkret situation där hen använder målspråket kommer att känna sig mer stimulerad att lära sig detta språk (Dörnyei \& Ushioda, 2009). Eftersom de flesta relevanta studier gjorts med vuxna som studerar engelska som L2 var det viktigt att komplettera dessa forskningsresultat genom att studera svenska ungdomar som lär sig franska som $\mathrm{L}_{3}$.

Studiens kvantitativa resultat visar överlag endast en liten effekt av aktiviteterna på elevernas ISFr och vilia till ansträngning. De kvalitativa resultaten visar däremot att aktiviteterna har stimulerat en större nyfikenhet för franska och främjat ett större samband mellan målspråket och deras egna livsplaner. Reaktionerna på ISFr-stimulerande aktiviteter kan dock vara negativa när elevens 
ISFr är för annorlunda än eller för långt bort ifrån hens allmänna självbilder. Dessa elever känner sig för lite berörda av det som händer i det franska språkklassrummet och vägrar, medvetet eller ej, att knyta an till, vare sig kognitivt eller emotionellt, till ämnet franska. Man kan fråga sig om situationen skulle vara annorlunda om liknande aktiviteter som de som användes i denna studie hade introducerats till dessa elever direkt när de började lära sig franska.

Ett annat viktigt resultat i studien är hur dynamiskt språkinlärningen är. När man undersöker en viss inlärningskontext samt individuella skillnader är det viktigt att komma ihåg att motivationsprocesser är individuella, komplexa och rörliga. Studiens resultat berör en viss grupp elever i den svenska skolkontexten som lär sig det franska språket men var och en av dessa elever har ett förflutet, en nutid och många drömmar som påverkar deras motivation att satsa, eller ej, på att lära sig det främmande språket.

Avslutningsvis kan konstateras att användandet av självbilder i språkundervisning, för de flesta elever i studien, har haft en övervägande positiv effekt och skulle kunna stödja lärare i deras motiverande roll, men forskningen inom området behöver fördjupas. Flera studier över olika tidsperioder, i olika inlärningskontexter och vid olika tidpunkter under språkinlärningen behövs för att kunna bekräfta betydelsen av denna strategi för språkundervisningen.

\section{Referenser}

Cardelús, E. (2016). Motivationer, attityder och moderna språk: en studie om elevers motivationsprocesser och attityder vid studier och lärande av moderna språk. [Doktorsavhandling, Stockholms universitet]. https://www.diva-portal.org/smash/get/diva2:886009 /FULLTEXTo3.pdf

Council of Europe/Skolverket (2009). Gemensam europeisk referensram för språk: lärande, undervisning och bedömning. Skolverket. https://www.skolverket.se/publikationer?id=2 I 44

Dörnyei, Z. (200I). Teaching and Researching Motivation. Longman. 
Dörnyei, Z., \& Chan, L. (2013). Motivation and vision: An analysis of future L2 self images, sensory styles, and imagery capacity across two target languages. Language Learning, 63, 437-462. https://doi.org/IO.I I I I/lang.I 2005

Dörnyei, Z., Csizér, K., \& Németh, N. (2006). Motivation, language attitudes and globalisation: A Hungarian perspective. Multilingual Matters.

Dörnyei, Z., \& Kubanyiova, M. (20I4). Motivating learners, motivating teachers: Building vision in the language classroom. Cambridge University Press.

Dörnyei Z., \& Ushioda, E. (2009). Motivation, Language Identity and the L2 Self. Multilingual Matters.

Dörnyei, Z., \& Ushioda, E. (2011). Teaching and Researching Motivation (2:a uppl.). Longman/Pearson.

Gardner, R. C. (I99I). Attitudes and Motivation in Second Language Learning. I A. Reynolds \& W. E. Lambert (Red.), Bilingualism, multiculturalism, and second language learning: the McGill conference in honour of Wallace E. Lambert (s. 43-64). LEA.

Gardner, R. C., \& Lalonde, R. N. (1985). Second Language Acquisition: A Social Psychological Perspective. Konferensbidrag presenterat vid the Annual Convention of the American Psychological Association, Los Angeles, California, USA.

Gu, M. M., \& Cheung, D. S. P. (20I6). Ideal L2 self, acculturation, and Chinese language learning among South Asian students in Hong Kong: A structural equation modelling analysis. System, 57 , I4-24. https://doi.org/IO.IOI6/j.system.20I6.0I.00I

Hadfield, J., \& Dörnyei, Z. (20I3). Motivating learning. Pearson.

Hammarberg, B. (20I4). Problems in defining LI, L2, L3. I A. Otwinowska \& G. De Angelis (Red.), Teaching and Learning in Multilingual Contexts: Sociolinguistic and Educational Perspectives (s. 3-1 8). Multilingual Matters.

Henry, A. (2012). L3 Motivation. [Doktorsavhandling, Göteborgs universitet]. Acta Universitatis Gothoburgensis. http://hdl.handle .net $/ 2077 / 28$ I 32 
Higgins, E. T. (1987). Self-discrepancy: A theory relating self and affect. Psychological Review, 94, 3 I9-340. https://psycnet.apa.org /buy/I987-34444-oo I

Jansson, B. (Io oktober 20I6). Skolans språkkris riskerar Sveriges konkurrenskraft. Dagens Nyheter. https://www.dn.se/debatt /skolans-sprakkris-riskerar-sveriges-konkurrenskraft/

Jauregi, K., De Graaff, R., van den Bergh, H., \& Kriz, M. (20I2). Native/non-native speaker interactions through video-web communication: a clue for enhancing motivation? Computer assisted language learning, 25, I-I9. https://doi.org/I0.I080/0958822I $.201 \mathrm{I} .582587$

Lozic, V. (8 oktober 2020). Motivation en viktig nyckel till elevers skolframgång. https://www.skolverket.se/skolutveckling/forskning -och-utvarderingar/forskning/motivation-en-viktig-nyckel-till -elevers-skolframgang

Lärarförbundet. ( 13 juni 20I 5). Från F till E - så ökar du elevernas studiemotivation. https://www.lararforbundet.se/artiklar/fran-f-till -e-sa-okar-du-elevernas-studiemotivation

Magid, M., \& Chan, L. (2OI2). Motivating English learners by helping them visualise their Ideal L2 Self: Lessons from two motivational programmes. Innovation in Language Learning and Teaching, 6, I I3-I25. https://doi.org/I0.I080/I750I 229.20I I.6I4693

Markus, H., \& Nurius, P. (1986). Possible Selves. American Psychologist, 4I, 954-969.

Masgoret, A. M., \& Gardner, R. C. (2003). Attitudes, motivation, and second language learning: A meta-analysis of studies conducted by Gardner and associates. Language learning, 53, I 23-163. https:// doi.org/IO.I I I I/I 467-9922.00227

Rajab, A., Far, H. R., \& Etemadzadeh, A. (20I2). The relationship between $\mathrm{L}_{2}$ motivational self-system and L2 learning among TESL students in Iran. Procedia-Social and Behavioral Sciences, 66, 4I9-424. https://doi.org/IO.IOI6/j.sbspro.20I2.II.285

Rocher-Hahlin, C. (20I4). Motivation pour apprendre une langue étrangère - une question de visualisation?: Les effets de trois activités en cours de français sur la motivation d'élèves suédois. 
[Licentiatavhandling, Lunds universitet]. Études romanes de Lund, 98. https://www.diva-portal.org/smash/record.jsf?pid=diva2 $\%_{3}$ A I I $76775 \&$ dswid $=$ I 826

Rocher Hahlin, C. (2020). La motivation et le concept de soi : Regards croisés de l'élève et de l'enseignant de français langue étrangère en Suède [Doktorsavhandling, Lunds universitet]. Études romanes de Lund, I09. https://www.diva-portal.org/smash/record .jsf? pid=diva2 \% 3 A I 42283 I $\&$ dswid $=$ I 826

Sampson, R. (2012). The language-learning self, self-enhancement activities, and self perceptual change. Language Teaching Research, I6, 3 I 7-335. https://doi.org/IO.I I77/I362 I688 I 2436898

Skolinspektionen (20I0). Moderna Språk. Skolinspektionens rapport 20Iо:6. https://skolinspektionen.se/globalassets/o2-beslut-rapporter -stat/granskningsrapporter/tkg/20 Io/moderna-sprak/slutrapport ---moderna-sprak.pdf

Sung, K. Y., \& Tsai, H. M. (20I3). Motivation and learner variables: Group differences in college foreign language learners' motivation. International Journal of Research Studies in Language Learning, 3, 43-54. https://doi.org/I0.586I/ijrsll.20I3.56I

Ushioda, E., \& Dörnyei, Z. (2009). Motivation, language identities and the L2 self: A theoretical overview. I Z. Dörnyei, \& E. Ushioda (Red.). Motivation, language identity and the L2 self (s. I-8). Multilingual Matters. 